\title{
Public participation in the brownfield redevelopment process: lessons learned in two case studies in Michigan, USA
}

\author{
A. P. Fontaine \\ Senior Urban Designer, JJR, LLC, USA
}

\begin{abstract}
This paper documents a defined approach for successfully engaging public participation in brownfield redevelopment projects. The two case studies vary by community size (140,000 to 870,000 residents) and by project area (17 acres to 3.5 miles of riverfront), but the basic approach stays the same. By comparing the two case studies, a list of lessons learned is generated and demonstrates how this basic approach can be applied to almost any brownfield redevelopment effort.

Keywords: participation, brownfields, Michigan, credible champion.
\end{abstract}

\section{Challenge of public participation}

The challenge in involving the general public in any development project is determining the optimum level of input the community should have in the process. Too little input and the project runs the risk of not gaining crucial community support - necessary for public funding, changes to adopted plans, and acceptance in the neighborhoods where change will take place. Too much input and the project will become unmanageable, responding to every nuance, local issue, and parochial concern.

Brownfield development projects add an additional layer of complexity in the public participation process. Brownfields often create many questions: What is a brownfield? How long has it been like this? What are the public health considerations? These are just a few of the more basic questions the public will have. The vast majority of residents will not understand the basic science involved in repairing the site, nor will they comprehend the complex regulatory conditions that must be met or the amount of effort that will be needed for a successful project to be created. 
All of these issues along with others create the largest obstacle for successful community involvement: the time it takes to redevelop a brownfield. To sustain interest and have meaningful input over the many years it takes for even the simplest of brownfield sites to be developed requires a detailed strategy designed to manage expectations. Share too much technical information early on and the community is either scared off, intimidated, or just tunes out. Print a colorful rendering of how the project may look in a decade in the newspapers and people expect changes immediately, will organize to fight it, or land speculation will run rampant - or all of the above.

\section{Public participation approach}

Working on brownfields in the United States' Midwest for the past 30 years, JJR, a land planning, landscape architecture, and civil engineering firm, has developed a basic approach for community involvement that applies to brownfields for communities of all sizes. The five fundamentals of the approach for creating successful public participation in brownfield redevelopment projects are as follows.

\subsection{The project narrative}

The community needs the technical information woven into an overall project narrative that gives context and translates the many details into a compelling reason why the brownfield redevelopment makes sense and is the right thing to do. Creation of this narrative, its refinement, timing, delivery, and manifestation in a design solution is at the very core of a successful public participation effort.

Why a project narrative? Because people remember stories and the larger arc, and can relate its meaning to their everyday lives. The language is more userfriendly and more detailed than a slogan or speaking points. No idea, bit of information, or news should be released to the public before it can be aligned with the larger project narrative. A small group (not more than 10-12 members) of key stakeholders (technical experts, civic leaders, key residents, institutional leaders) should preside over the considerable effort of managing the evolution of the project narrative.

The project narrative explains what the project is, and the benefits and reasons for undertaking it while framing the issues and setting the table for public support. Most importantly, the narrative manages expectations. By actively managing the narrative, the community's expectations are in line with the reality of the site, the market, and the overall project vision.

Managing expectations is especially important in communities that have been suffering great economic, cultural, and social losses. Even larger communities only get so many chances to turn the tide of disinvestment, and no one project can by itself transform a community's fortunes. Residents often expect too much from a single project, or they fear that if it isn't successful, the town is doomed. The reality is always somewhere in the middle, and it is the job of the narrative to find that middle ground of realistic optimism while encouraging active and 
meaningful community participation. Once a community understands the value of a project narrative, the approach for managing public participation becomes a much simpler affair.

\subsection{Support a credible champion}

Consultants play a key role in the process: organizing meetings, developing technical plans, designing solutions, and managing the development process, but they can not be seen as leading the effort. The community needs to hear the vision and its issues from an elected or at least a widely acknowledged public figure. The leader needs to have the trust of the community, be able to communicate at the community level, and have strong ties to both the public and private sector. For a transformative project that will affect an entire city, the mayor, city manager, or leader of a larger non-profit will need to step up to the role for the project to attract the level of attention it deserves. The leader must champion the project through the entire process for success to be achieved.

\subsection{Take small, connected steps, and stick to a simple schedule}

The shortest brownfield redevelopment projects have a timeline of at least three years, and these are the exception. A typical timeline can stretch more than six to eight years depending on the size of the project, the authorities involved, and the level of remediation needed (necessary repairs to the site).

Few projects have the ability to sustain public interest over an extended period of time (two years is usually the maximum time any one resident can be expected to follow in detail a specific aspect of the project). Therefore, it is important to establish larger project goals and then break the project into smaller, two-year phases that respond and relate to the larger goals. Here is an idealized example:

- $\quad$ Phase 1: Understanding remediation issues - what will it take to repair/fix the site? Years 1-2. Phase 1 covers technical issues and determines project limits, jurisdictions and roles, and possible approaches to repairing the site.

- Phase 2: What is possible - defining the vision! Years 3-4. Topics include overall project goals and standards, ways of measuring success, understanding market and site conditions, and crafting a defined solution.

- Phase 3: Getting the vision built. Years 4-6. The focus of phase 3 is finding private and public sector partners to build the vision - marketing the project beyond the confines of the community.

- $\quad$ Phase 4: Expanding the vision. Year 7-onward.

Each phase builds on the previous one, creating further refinement on issues and the overall design while building support for the project in a way the public can follow and understand. A strict and simple schedule must be maintained throughout, linking the phases. Quarterly community workshops and monthly updates on a website and through the local newspapers are standard and effective methods of making sure everyone is on the same page. 


\subsection{Manage the project narrative}

One constant in brownfield projects is that things change: consultants change, leaders change, and issues change, but the underlying narrative of why the brownfield project is important must remain the same. Narratives are userfriendly ways of communicating complicated technical data so that while people may not understand all of the details, they are able to follow the broader issues.

Specific issues that arise need to be integrated into the project narrative. By doing so, the narrative keeps up with current events and responds to specific topics (e.g., how traffic in a particular neighborhood is going to be impacted).

Support is quickly lost when the community starts to hear different views on the same topic. The more muddled the narrative, the less people will understand it and believe in it, eroding support and the overall feasibility of the project. Larger projects need to develop a public relations strategy that includes recruitment of key media players to foster a healthy relationship with newspapers, internet sources, radio programs, and television stations.

When the revised narrative has been determined, it needs to be continuously released through many kinds of media through one media contact person. When people don't hear about a project, rumors begin to circulate. By being proactive, the brownfield redevelopment team can frame the issues and minimize any disruptive rumors or damage done by uninformed critics. The credible leader should be the one delivering any major breaking news.

\subsection{Design flexible solutions}

Brownfields are like house renovations - there is no knowledge of what might be encountered until the job has started. Until the construction equipment is at the site, and digging and debris removal has begun, there cannot be $100 \%$ certainty as to what will be found and how it may influence the final design. The public needs to understand that changes can occur at any stage of the process and that deadlines may need to be extended - all part of aligning and managing expectations.

\section{Case studies}

Both case studies are located in Michigan. Michigan is experiencing a profound transition, moving rapidly from an industrial manufacturing base to a knowledge-based economy. While home to an outstanding collection of public universities, protected natural environments, and an established transportation network, the transition has been an extremely difficult one for the local population. Michigan is one of two states that have lost population since 2000 (2005 U.S. Census) and has witnessed seven consecutive years of net job losses - more than 300,000 manufacturing jobs alone have been lost since 2000 .

This transition is most evident in the city of Detroit. Detroit is the home of the American automobile industry and Michigan's largest city. The city is less than $50 \%$ of its peak population and continues to lose more than 1,000 residents 
a month. Detroit has among the highest rates of poverty, unemployment, and crime in the nation. In short, it is a city in a state that is in need of transformative projects.

Taken together, the two case studies represent communities looking to proactively shape their future. Not content with letting the market determine their future, the two communities decided to use civic facilities as a way of leading by example in an attempt to encourage future economic development. Because each of the case studies centers on civic facilities (a city hall and a riverfront park) and the general anxiety about the future of the region, effective public participation was essential.

Population: 140,000

Project site: 17 acres, located in city's civic center

Brownfield issues: Existing city hall; vacant county building; parking lots

Project timeline: 1998-2007

Major project players: City of Warren Mayor's Office and Departmental Staff, JJR, Neumann/Smith Architecture, Skanska USA, Hubbell, Roth \& Clark, Inc.

Project program: 112,000 sf city hall/library, 632space parking structure, 2-acre city square, and 14 blocks of streetscape

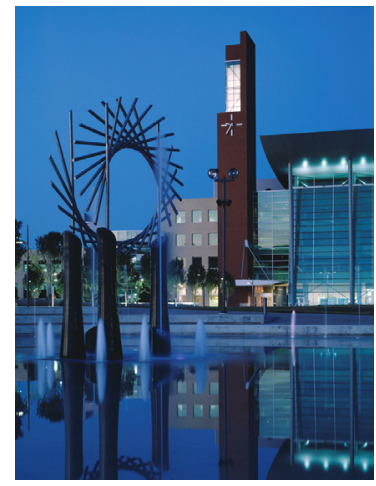

Figure 1: $\quad$ City of Warren.

\subsection{City of Warren}

\subsubsection{The project narrative}

Founded in 1957, Warren was built around the 900-acre General Motors Technical Center, home to more than 21,000 employees working on automobile engineering and styling for all General Motors products. Additional manufacturing plants and automobile factories soon called Warren home, and the town quickly grew with vast neighborhoods of single-family homes and strip commercial corridors. What was envisioned to be the town's downtown evolved into a series of disconnected buildings surrounded by acres of parking lots further separated by wide boulevards.

By the mid 1980s, population growth stopped, housing values stagnated, and industry began leaving the city for cheaper locations. By 1998, the beginning of a comprehensive visioning effort, the city was slowly losing population, blight was developing on the edges of the community, and there was talk that General Motors would soon leave. Mayor Steenbergh knew that the city needed to act quickly and make a significant investment in its future.

The comprehensive visioning effort focused on what areas needed to be revitalized to appeal to younger workers while offering new retail and housing opportunities to existing residents. Of the six corridors and districts identified, the highest priority was assigned to the city's failed downtown. Through a series 
of workshops and public meetings, it was determined that a new downtown, complete with a new city hall and library, would be built. The project was completed in 2007 , in time for the city's $50^{\text {th }}$ birthday celebration that attracted more than 25,000 residents to the new city center.

While it was an expensive undertaking $(\$ 75,000,000$ through bonding covered by tax increment financing), more than $80 \%$ of the residents who attended workshops favored the project. In one setting, the attendees saw maps that outlined the growth of blighted areas, saw examples of other communities that revitalized themselves through the creation of a new civic center, and heard of the need to create an environment that would appeal to a younger generation. Of particular interest were the 21,000 employees of the General Motors Technical Center - more than half are under the age of 40 , and of those, less than $2 \%$ live within a 5 -mile radius. The average income of a General Motors Technical Center employee is more than $\$ 80,000$, and very little of that money was staying within the community.

The narrative that guided the project from day one was the need for Warren to be competitive and attract the next generation of workers and employers to the community - things could not stay the same. Residents could see the devastating effects of blight, being so close to Detroit, and it began to creep into their neighborhoods. Waiting wasn't an option. The narrative spoke directly to what the residents were experiencing and addressed their fears/concerns in a positive manner. The ultimate message of the narrative was hopeful and positive - this is the dawn of Warren's next great era.

One aspect that could have been improved upon in the narrative was to better explain how a healthy community center helps all neighborhoods. The few vocal complaints of the project have been that existing residential neighborhoods have been neglected in favor of building a downtown for newcomers. While the idea of the center helping improve the quality of life for all residents was stressed in later phases, it did not fully take root with those nearest to and in blighted areas.

\subsubsection{Support a credible champion}

The project could not have had a better credible champion. Mayor Steenbergh was an extremely popular mayor who saw the need for his community to change with the times. He put the success of the project on his shoulders and made sure every detail was looked after, and that it represented the values and beliefs of the residents. Mayor Steenbergh made the new city center a focal point of all of his speeches, was completely available to the media, and took an active role in recruiting private sector partners. The mayor was also active in selecting the artist for the monument in the new city square and participated in design charrettes. The project would not have been completed on time, at such a high level of execution without the mayor's ongoing support and drive, or the complete support he had from City of Warren staff.

\subsubsection{Take small, connected steps, and stick to a simple schedule}

It is essential for transformative projects to have a separate and dedicated group of individuals whose main task is to ensure a successful effort. Hiring a separate project management firm ensured that all parties were on the same page, and 
knew of meetings and internal deadlines, and that issues were comprehensively covered. Having a defined goal of completing the project in time for Warren's $50^{\text {th }}$ birthday gave everyone a clear target. By starting the planning for a new downtown in 1998 for a phase 1 completion in 2007, no steps were rushed or overlooked, and details were carefully and meticulously addressed.

\subsubsection{Manage the project narrative}

A quarterly newsletter updated residents on the project's progress. It was made available in print at the existing city hall and online on the City of Warren's website. All meetings held in connection with the project were shown on the community's television access channel, and input from residents was welcomed via the Internet. A day-to-day point person was chosen to handle inquiries and feedback from residents and interested development parties, and to handle media requests.

The point person, Gina Cavaliere, the Downtown Development Authority director, was an integral part of the project's success. She not only wrote the newsletter, but also met with dozens of contractors, assisted in scheduling events to announce the project, and found additional funds to complete the public art in the city square. A valuable lesson learned was recognizing the importance of the point person. There are hundreds of day-to-day items that need to be prioritized and addressed. All of the steps of a carefully thought out plan can be in place, but without an organized and highly effective point person on the community's side, the project will not succeed.

\subsubsection{Design flexible solutions}

Warren is currently in the process of selling the 17 acres that surround its new city hall, library, and city square. The land for sale is governed by newly adopted urban design guidelines that allow many different land uses, design approaches, and exterior materials. The importance of the city hall and related civic uses are protected through massing, restrictions on entrances, and the shielding of loading docks, parking areas, and HVAC systems. Warren understands that great cities grow over time and require a flexible approach to allow for new ideas and technology. They are entering year 11 of their transformation and are continuing to manage the narrative while visible results are being built every year.

\subsection{City of Detroit}

\subsubsection{The project narrative}

The city of Detroit has been losing population and jobs for the last 40 years. Almost 50\% of newborns are born into poverty - by far the highest rate for an American city. In 2000, according to the City of Detroit's records, less than 1,000 hew housing units had been created in the last two decades, while more than 10,000 vacant homes were removed in that same time period, with an additional 8,000 on the list to be removed as well. The one bright spot has been the city's downtown. With the announcement and construction of two new 
Population: 871,121

Project site: City of Detroit's East RiverWalk, from Hart Plaza to Belle Isle, a distance of 3.5 miles

Brownfield issues: Heavy metals; PCBs; obsolete/abandoned structures; landfills; rotting structural supports adjacent to river; other related industrial issues

Project timeline: 2000-2007

Major Project players: Detroit Riverfront Conservancy, City of Detroit, JJR, SmithGroup, Hines, White/Olson

Project program: 3.5 miles of continuous pathway along the Detroit River, punctuated by six plazas offering a variety of recreational activities

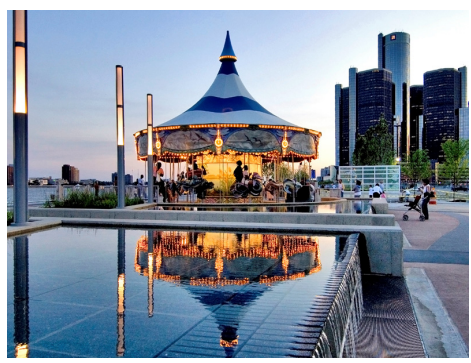

Figure 2: $\quad$ City of Detroit.

stadiums and the renovation of the Renaissance Center - an office complex of more than 3 million square feet of office space converted into the General Motors (GM) World Headquarters - things started looking up.

Hart Plaza was the one public space in downtown that offered access to the Detroit River. It was designed to hold large festivals. Cut off from the rest of the city by an 8-lane road, a 12-lane entrance into the Detroit-Windsor Tunnel, and a private office building, most of the time the plaza felt empty and did not offer any amenities other than views, a large fountain that didn't work, and sun.

The rest of the riverfront was either inaccessible because of private ownership or offered no safe place to sit or walk. If the emerging success of the downtown could be stretched to other parts of the city, it would be along the Detroit River. Many other former industrial cities in the region have converted their waterfronts into park land and successful new neighborhoods to complement their downtown. Detroit firmly believed in this model and started planning for a major riverfront park in 2000.

The project had to be positioned carefully. Many residents thought too much attention and civic resources had already been given to the downtown. Therefore, the announcement of the RiverWalk - the project's official name was positioned as bringing the river back to the people of Detroit. It was a project for everyone - in the most racially segregated major city in North America, that can be a very difficult sell. The RiverWalk was envisioned to be the place to stroll along the river for many miles, next to cafés, new apartments and town homes, and revitalized neighborhoods. Nowhere in Detroit could a person walk next to the river and be near a café, town home, or even an office.

\subsubsection{Support a credible champion:}

Detroiters have become weary of large projects. Many major revitalization projects had been promised over the last 40 years. Most never happened, and the few that did very rarely delivered what was promised, with the most famous example being the original Renaissance Center (Ren Cen). The Ren Cen was 
billed as the rebirth of the entire city of Detroit when it was opened in 1977. Instead, its size and location emptied many existing office buildings into what had been called a suburban bunker. Once in the Ren Cen, few workers ventured out into the city. The city was not saved.

For this project to receive the community backing it needed, a champion with a track record was mandatory. In fact, two champions working together were needed. Matthew Cullen (General Manager, Economic Development and Enterprise Services, General Motors Corporation, and Co-Chair of the Detroit Riverfront Conservancy) and Derrick Miller (Chief Information Officer with the Mayor's Office) worked together from land assemblage to ribbon cutting. Together, they formed a credible champion team that was able to handle issues of race, present a proven track record, and have the experience in communicating both public policy and real estate goals.

\subsubsection{Take small, connected steps, and stick to a simple schedule}

The completion goal for the RiverWalk was easy to communicate once Detroit was chosen to host the 2006 Super Bowl - the largest single-day sporting event in North America. While January is not the ideal time to enjoy a walk along the Detroit River, it became a matter of pride. When the world was in town for the Super Bowl, the RiverWalk had to be ready. With that goal firmly set and Detroit wanting to demonstrate that it was on its way back, the schedule fell into place with all stakeholders involved.

\subsubsection{Manage the project narrative}

The fundamental narrative of giving the river back to the community has proven to be a durable and successful message. Over the two-year planning period, there were more than 12 community workshops to ensure that the final plan represented a place that reflected the values and needs of the local residents. The phasing of the workshops allowed residents to offer input on different levels of detail, from master planning to final programming and site details. The workshops even helped shape the characters on the extremely successful carousel ride. Strategically timed press releases, feature articles in the major newspapers, and a special on the coming attractions of the RiverWalk ran on television.

The creation of the Detroit Riverfront Conservancy (DRC) has created a onestop shop for all things RiverWalk. The DRC gives the citizens of Detroit a way of not only learning more about the project as it grows towards the east side of the city, but also a chance to get involved and even learn about the local ecology. It is another example of giving the river back to the community - an extremely active way to manage the narrative.

\subsubsection{Design flexible solutions}

There were more than 10 different ownership groups to negotiate in creating the RiverWalk. Getting everyone to agree within the timeline of the Super Bowl became one of the most challenging aspects of the project. As the deadline approached, it became clear that a few temporary solutions would need to be in place in order to meet the larger goal of having a continuous pedestrian experience. At times, the path needed to head inland, more than 200 feet away 
from the Detroit River's edge. There were, and are, ongoing lawsuits, and there are still brownfield issues not completely resolved, but the larger goal of having a place to take a stroll along the river, complete with cafés, carnival rides, nature, and places to sit quietly was accomplished. In the year that it has been completed, a new 80-unit apartment complex has been constructed and three additional mixed use projects have been approved.

\section{Conclusion}

Of the five fundamentals outlined in this paper (The Project Narrative; Support a Credible Champion; Take Small, Connected Steps, and Stick to a Strict Schedule; Manage the Narrative; and Design Flexible Solutions), the most important for achieving success is having a credible champion. None of the case study projects would have gone on to become award-winning developments or held up as Best Practices without a well-received credible champion. The case studies show that a proven track record is an essential ingredient for a credible champion along with being highly visible and managing the other three components.

One final lesson is the need to celebrate small successes and to have fun along the way. Brownfield redevelopment requires patience, but it also needs inspiration. The payoff cannot only come at the ribbon cutting -5 to 10 years after the start of the process. Using the site for a marathon, a county fair, or for holiday decorations (all actual events within the case studies) can help to keep people engaged and hopeful that positive things can happen. Successful public participation in the brownfield redevelopment process maintains a positive outlook and gets things done through active management and alignment of the project's credible champion, narrative, schedule, and ongoing communications.

\section{References}

[1] Cavaliere, Gina, Personal Communications, September-December 2007, Downtown Development Authority Director, City of Warren, Michigan

[2] Miller, Derrick, Personal Communications, September-December 2007, Chief Information Officer, City of Detroit Mayor's Office, Detroit, Michigan

[3] Ford School of Public Policy, Personal Communications, SeptemberDecember 2007, University of Michigan, Ann Arbor, Michigan

[4] Editorial Board, Personal Communications, September-December 2007, The Detroit News, Detroit, Michigan

[5] Office of the Governor, Governor Jennifer M. Granholm, Personal Communications, September-December 2007, State of Michigan, Lansing, Michigan 